\title{
Investigation of thermal degradation of hydrolysis lignin
}

\author{
Pavel Maryandyshev ${ }^{1, *}$, Aleksei Kangash ${ }^{1}$, and Victor Lyubov ${ }^{1}$ \\ ${ }^{1}$ Northern (Arctic) Federal University, Naberezhnaya Severnoy Dviny 17, Arkhangelsk, 163002, \\ Russia
}

\begin{abstract}
Wood hydrolysis facilities were built in both northern and southern European regions of Russia, as well as in Siberia and the Russian Far East. Other hydrolysis plant in the former USSR were located in Ukraine, Belarus, Uzbekistan, Kazakhstan, Moldova and Lithuania. All or most of these facilities produced substantial amounts of excess lignin, socalled "hydrolysis lignin" (HL). Technology of energy utilization of HL, having a great potential is a production of granulated fuel. Perspective way is pelletization of HL. In this paper complex kinetic analysis of hydrolysis lignin and its organic components under conditions of dynamic and isothermal heating was carried out. Kinetic parameters are determined using the extended independent parallel model.
\end{abstract}

\section{Introduction}

Recently more attention is being paid to wood biofuels, which are renewable energy sources and take the fourth position in the world energy balance after coal, natural gas and oil that are connected with some factors. One of these factors is development of wood biomass energy utilization technologies. Thus, there is a huge possibility of utilization of side product of wood treatment - lignin which is $40 \%$ of dry mass of wood [1].

In the technological cycle of hydrolysis industry lignin is being produced, which is a complex of components of different chemical structure. Hydrolysis lignin is composed of: mainly of changed lignin of vegetative cellulose (40-88\% of dry mass); polysaccharides (13-45\%); components of lingo humic complex (5-19\%); non-washed monosaccharides after hydrolysis process; mineral and organic acids: mainly sulphur, formic and acetic, ashes and some other components [2,3].

Acid hydrolysis of wood and agricultural residues for the production of ethanol, fodder yeast, hexose and pentose sugars and their derivatives (i.e. furfural and xylitol) had industrial applications in Soviet Union and Bulgaria [4]. It was based mainly on percolation hydrolysis using diluted $\mathrm{H}_{2} \mathrm{SO}_{4}$, which was developed in the former USSR and used from the 1930 s to the 1990s, although some semi-industrial facilities for wood or agricultural residue hydrolysis using concentrated $\mathrm{HCl}$ were also used during this period. Wood hydrolysis facilities were built in both northern and southern European regions of Russia, as

\footnotetext{
* Corresponding author: p.marjyandishev@,narfu.ru
} 
well as in Siberia and the Russian Far East. Other hydrolysis plant in the former USSR were located in Ukraine, Belarus, Uzbekistan, Kazakhstan, Moldova and Lithuania. All or most of these facilities produced substantial amounts of excess lignin, so-called "hydrolysis lignin" (HL). In spite of the fact that there were energy utilizing boilers, they were not able to use all hydrolysis lignin for the energy production and main part of HL was stored in dumps.

Technology of energy utilization of HL, having a great potential is a production of granulated fuel [1]. Perspective way is pelletization of HL. And combination of the preliminary torrefaction process of HL before its pelletization (isothermal heating at 250 $300^{\circ} \mathrm{C}$ without oxygen) of the initial $\mathrm{HL}$ will lead to receiving a new product with better heating values: energy yield and density. First experience of such plant in the Arkhangelsk region of the Russian Federations shows that pellets from HL has calorific value not lower than $21,34 \mathrm{MJ} / \mathrm{kg}$ (with $\mathrm{W}_{\mathrm{r}}=6,27 \% ; \mathrm{A}_{\mathrm{r}}=2,45 \%$ ).

Therefore, a huge interest is being raised to the energy utilization of the hydrolysis lignin in the Russian Federation. For the effective energy utilization of the HL it is necessary to study deeply its characteristics, process of thermal degradation and combustion, to analyze gas components and ashes during the process of thermal degradation, to carry out comparison with classical wood fuel (spruce, pine). In this paper thermogravimetric curves were constructed, gas components were determined, and kinetic parameters were calculated using an extended independent parallel model. The results were compared with parameters of classic wood fuels.

\section{Materials and methods}

Wood fuel of various species (spruce and pine trunk, spruce and pine bark, hydrolysis lignin) were used during the investigation for comparisons.

The content of carbon, hydrogen, nitrogen and sulphur was determined using the EuroVectorEA-3000 analyser, and oxygen was calculated from the mass balance.

The thermotechnical characteristics of the test samples were determined in accordance with State Standard 54185-2010, 54186-2010, and 54211-2010. Net calorific values were determined using an IKA C 2000 Basic version 2 bomb calorimeter.

For a deeper understanding of the processes of thermal decomposition and combustion of wood fuels, it is necessary to know what components they consist of. For this, X-ray fluorescence analysis was performed.

Samples were dynamically heated to produce thermogravimetric curves. Experiments were carried out using a synchronous thermal analyzer Netzsch STA 449 F3.

For isothermal heating 250-mg sample was placed in the crucible of the reactor with a special spoon and heated from ambient temperature $\left(20^{\circ} \mathrm{C}\right)$ to a temperature of $550^{\circ} \mathrm{C}$; then, it was kept under isothermal conditions for an hour under air, which was obtained mixing of nitrogen with oxygen (Fig. 1). The analyser of gas components (Anapol EU 5000), which consists of electrochemical cells for the determination of $\mathrm{CO}, \mathrm{CO}_{2}, \mathrm{O}_{2}$, and total hydrocarbons, allowed to perform continuous measurements.

Kinetic parameters were calculated using extended independent parallel model (EIP). The EIP model combines the parallel processes of thermal degradation of the three organic components of wood biomass (hemicellulose, cellulose and lignin). To implement this method, the ratio coefficients for hemicellulose, cellulose and lignin must be determined, which is not an easy task [5]. In this paper, the desired relations were determined from differentiated thermogravimetric curves and were calculated from the results of modelling. 


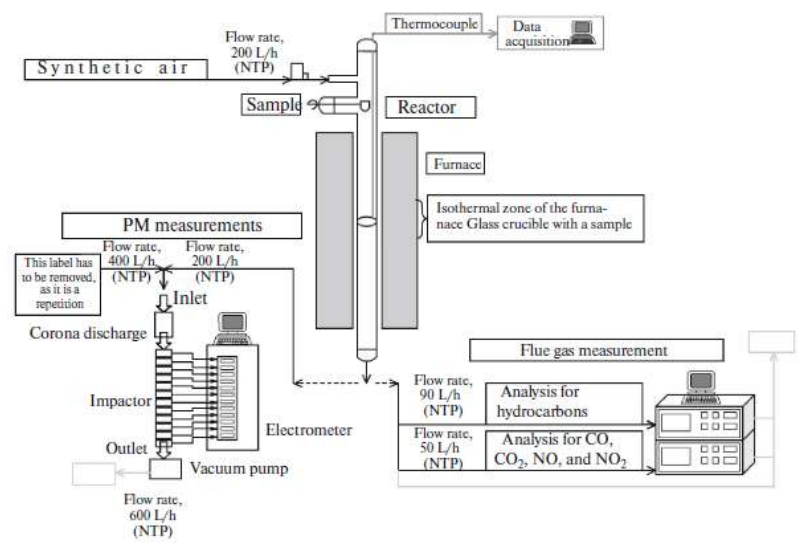

Fig. 1. Schematic diagram of the experimental installation for the determination of gas components and fine particles emitted during the thermal decomposition and combustion.

\section{Results and discussion}

The elemental composition of hydrolytic lignin is shown in Table 1.

Table 1. The elemental composition of hydrolytic lignin.

\begin{tabular}{|l|c|c|c|c|c|}
\hline & $\mathrm{C}(\%)$ & $\mathrm{H}(\%)$ & $\mathrm{N}(\%)$ & $\mathrm{S}(\%)$ & $\mathrm{O}(\%)$ \\
\hline $\begin{array}{l}\text { Hydrolysis } \\
\text { lignin }\end{array}$ & 52,6 & 5,8 & 0,2 & - & 29,8 \\
\hline
\end{tabular}

The results of proximate analysis are shown in Table 2.

Table 2. Proximate analysis.

\begin{tabular}{|l|c|c|c|c|}
\hline \multicolumn{1}{|c|}{ Sample } & $\begin{array}{c}\text { Moisture } \\
\mathrm{W}_{\mathrm{a}}(\%)\end{array}$ & $\begin{array}{c}\text { Ash content } \\
\mathrm{A}_{\mathrm{a}}(\%)\end{array}$ & $\begin{array}{c}\text { Content of } \\
\text { volatile } \\
\text { organic } \\
\text { component } \\
\mathrm{V}_{\mathrm{a}}(\%)\end{array}$ & $\begin{array}{c}\text { Net } \\
\text { calorific } \\
\text { value } \\
\mathrm{Q}_{\mathrm{i}}{ }^{\mathrm{r}}(\mathrm{kJ} / \mathrm{kg})\end{array}$ \\
\hline Hydrolysis lignin & 8,6 & 3,0 & 57,8 & 19315 \\
\hline Spruce (trunk) & 6,9 & 1,0 & 79,1 & 17028 \\
\hline Spruce (bark) & 11,6 & 2,2 & 65,5 & 16982 \\
\hline Pine (trunk) & 7,4 & 0,3 & 79,1 & 17313 \\
\hline Pine (bark) & 9,5 & 2,5 & 68,6 & 17292 \\
\hline
\end{tabular}

Classical TG and DTG curves in Figures 2-3 describe the evaporation of moisture and volatile substances. Considering hydrolysis lignin, it can be distinguished 3 main zones. The first zone, in the temperature range from 20 to $140{ }^{\circ} \mathrm{C}$ with a weight loss of about $10 \%$ is characterized by evaporation of moisture. The second zone is the zone of active pyrolysis, corresponds to a temperature range of $250-400{ }^{\circ} \mathrm{C}$. In this zone, the main mass loss occurs (from 45 to $60 \%$ depending on the type of fuel), the thermal degradation of hemicellulose and cellulose that make up the components of wood biofuels occurs. The third zone is in the temperature range from 400 to $800{ }^{\circ} \mathrm{C}$ and characterizes the process of passive pyrolysis when there is a prolonged thermal degradation of organic substances, mainly lignin. The mass loss in this range is from 10 to $15 \%$, depending on the sample. 


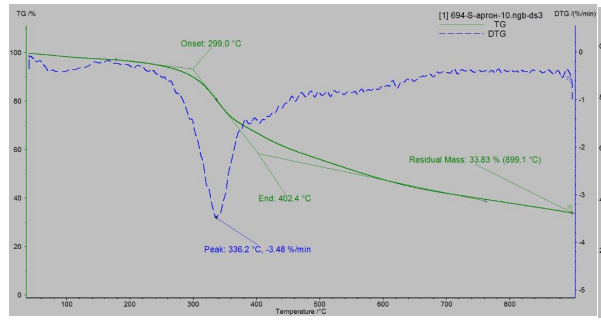

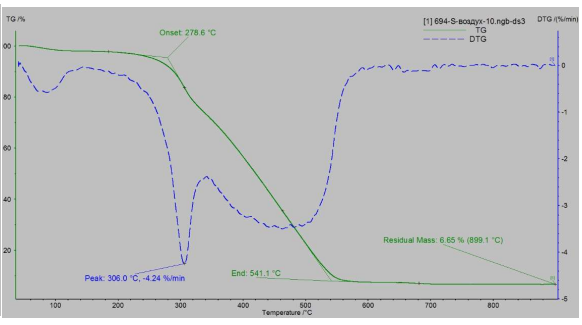

b

Fig. 2. TG and DTG curves for the thermal degradation of hydrolysis lignin under inert atmosphere (a) and under air (b)

Figure 3 illustrate data on the gas components $\mathrm{CO}, \mathrm{CO} 2$, and hydrocarbons for hydrolysis lignin: the decomposition of the organic components of the test materials begins at a temperature of about $200^{\circ} \mathrm{C}$. The release of gases reaches a maximum at $380-400^{\circ} \mathrm{C}$ with the simultaneous combustion of volatile substances and of the coke residue. A lower volatile content and a considerably higher ash content in the hydrolytic lignin are responsible for a lower concentration level of the resulting gaseous components (to 8000 $\mathrm{ppm}$ ) than that in the case of the spruce wood (to $11000 \mathrm{ppm}$ ). Note that carbon dioxide predominated in the resulting gaseous components.

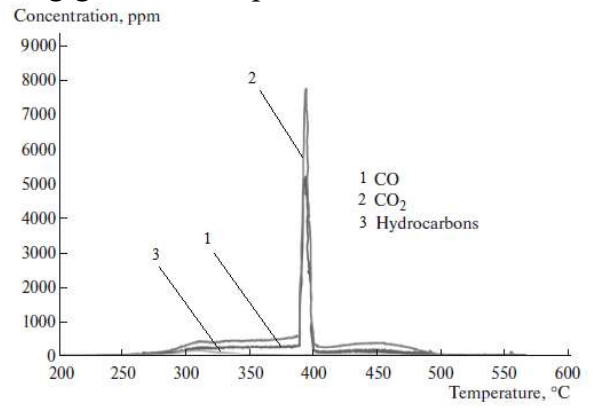

Fig. 3. Gas components formed in the course of the thermal decomposition and combustion of hydrolysis lignin

Table 4 shows the kinetic parameters for hydrolysis lignin in the inert and air atmosphere, determined by the EIPR model. This model is being mainly developed by the scientists of the Laboratory of Risk Analysis of the University of Haut Alsace [7].

Table 4. Kinetic parameters for hydrolysis lignin.

\begin{tabular}{|l|l|l|l|l|}
\hline \multirow{3}{*}{ Sample } & \multicolumn{3}{l|}{ Kinetic parameters } \\
\cline { 2 - 5 } & Nitrogen atmosphere & \multicolumn{2}{l|}{ Air atmosphere } \\
\cline { 2 - 5 } & $A\left(\mathrm{~s}^{-1}\right)$ & $E_{\alpha}(\mathrm{kJ} / \mathrm{mol})$ & $A\left(\mathrm{~s}^{-1}\right)$ & $E_{\alpha}(\mathrm{kJ} / \mathrm{mol})$ \\
\hline Hemicellulose & $1,8 \cdot 10^{4}$ & 78,0 & $1,8 \cdot 10^{4}$ & 79,0 \\
\hline Cellulose & $1,1 \cdot 10^{4}$ & 87,0 & $4,1 \cdot 10^{7}$ & 115,0 \\
\hline Lignin & 10,1 & 60,0 & 10,1 & 50,0 \\
\hline Coke residue & - & - & $6,0 \cdot 10^{4}$ & 99,0 \\
\hline Error & 0,013 & & 0,035 & \\
\hline
\end{tabular}

\section{Conclusions}

Complex kinetic analysis of hydrolysis lignin and its organic components under conditions of dynamic and isothermal heating was carried out. Hydrolysis lignin has good composition elements and results of the proximate analysis are quite similar to results of the classical 
wood. Kinetic parameters are determined using the extended independent parallel model. The obtained experimental data allowed to conduct comparison of calculated results with experimental ones using thermogravimetric and differential-thermogravimetric curves. The error obtained with the use of the extended independent parallel model has lower values than for the differentially isoconversional method. Next step is the optimization of the process of thermal degradation and combustion in heat generating equipment using kinetic parameters.

\section{References}

1. Rabinovich, M.L., Fedoryak, O., Dobele, G., Andersone, A., Gawdzik, B., Lindstrom, M.E., and Sevastyanova, O., Renew. Sust. En. Rev., 57, 1009 (2016)

2. Lyubov, V.K. and Lyubova, S.V., Povyshenie effektivnosti energeticheskogo ispol'zovaniya biotopliv (Enhancement of the Efficiency of the Power-Generation Use of Biofuel) (Arkhangelsk, 2010)

3. Mahmood, N., Yuan, Z., Schmidt, J., and Xu, C.C., Biores. Technol., 74, 4 (2015)

4. Rabinovich, M., L, Cell. Chem. Technol., 44, 174 (2010)

5. Rueda-Ordonez, Y.J. Tannous. Isoconversional kinetic study of the thermal decomposition of sugarcane straw for thermal conversion processes (Bioresource technology, 2015)

6. Carrot, P.J.M., Suhas, A., Carrot, M.M.L., Guerrero, C.I.,and Delgado, L.A., J. Anal. Appl. Pyrol., 82, 264 (2008)

7. Popova, E., Chernov, A., Maryandyshev, P., Brillard, A.,Kehrli, D., Trouve, G., Lyubov, V., and Brilhac, J.-F., Biores. Technol., 218, 1047 (2016). 